\title{
Türkiye'de Çok Partili Sisteme Geçiş: İç ve Dış Dinamiklerin Analizi ${ }^{1}$
}

\author{
Vahap ULUÇ \\ Dr. Öğr. Üyesi, Harran Üniversitesi, İ̈BF, Kamu Yönetimi Bölümü \\ ulucvahap@yahoo.com \\ Orcid ID: https://orcid.org/0000-0002-2782-4451
}

\begin{abstract}
$\ddot{\mathbf{O z}}$
Bu çalışma, Türkiye'nin çok partili siyasal sisteme geçişinin iç ve dış nedenlerini konu edinmektedir. Türkiye gibi geç modernleşen ülkelerde, Batı'dan farklı olarak halktan bağımsız dinamikler çok partili sisteme geçiş sürecini belirlemiştir. Türkiye'nin çok partili sisteme geçişi iç ve diş olmak üzere iki temel dinamiğe dayanmaktadır. İçerde ekonominin kötü gidişatına bağlı iktidardan iyice soğuyan geniş halk kesimleri ve sermaye gruplarının iktidardan pay almak istemeleri belli ölçüde çok partili sisteme geçişi etkilemiştir. Ancak çok partili sisteme geçişte asıl belirleyici unsur Türkiye'nin ABD ve Batı'ya yanaşma ihtiyacı hissetmesi ve Sovyetler Birliği'nin Türkiye için ciddi bir tehdit haline gelmesidir.
\end{abstract}

Anahtar Kelimeler: Türkiye, Çok Partili Sistem, İç Dinamikler, Dış Dinamikler.

\section{Transition to Multiparty System in Turkey: An Analysis of Internal and External Dynamics}

\begin{abstract}
The subject matter of this study is the internal and external cause of the transition of Turkey to as multiparty system. In contrast with the West, dynamics independent from the public had determined the process of transition to the multiparty system in countries modernizing in later periods like Turkey. Transition of Turkey to the multiparty system is based on two main dynamics, namely, the internal and external dynamics. The large masses displeased with the government as a result of the poor course of the economy and some capital groups

${ }^{1}$ Makale Geliş/Kabul Tarihi: 04.09.2019 / 14.04.2020

Künye Bilgisi: Uluç, V. (2020). Türkiye'de Çok Partili Sisteme Geçiş: İ̧̧ ve Dış Dinamiklerin Analizi. Kahramanmaraş Sütçü Imam Üniversitesi Sosyal Bilimler Dergisi, 17 (1), 465-486. DOI: 10.33437/ksusbd.615325
\end{abstract}


wishing to take their shares from the power in the country had been effective on the transition to the multiparty system to a certain degree. However, the main determining factors in the transition to the multiparty system the need of Turkey to get closer to the West and the US, and that the Soviet Union had become a serious threat for Turkey.

Keywords: Turkey, Multiparty system, Internal Dynamics, External Dynamic.

\section{GİRIŞ}

Türkiye'nin siyasal modernleşme tarihi, uzun soluklu bir sürece dayanmaktadır. Burada siyasal modernleşmeden kast edilen, siyasal gelişme anlamında demokratikleşmedir. Türkiye'nin coğrafi olarak Avrupa'ya komşu olmas1 demokratikleşme sürecini olumlu etkileyen bir unsur olmuştur. Demokratikleşme sürecini iki ana gelişme seyrine bağlamak mümkündür. Birincisi, toplumun iç dinamiklerine dayanan evrimci demokratikleşme süreci, ikincisi ise aydın, sivil ve askeri bürokratik elitler eliyle gerçekleştirilmeye çalış1lan devrimci demokratikleşme sürecidir. Türkiye geç-modernleşen ülkeler kategorisinde yer alıp, demokratikleşme çabaları ikincisine uygun düşmektedir.

Türkiye siyasetinde 19. yüzyıldan itibaren padişahın bazı yetkilerinin kısıtlanmasıyla başlayan demokratikleşme süreci, 1946 'da çok partili hayata geçiş ile birlikte yeni bir ivme kazanmıştır. Elbette, çok partili hayata geçiş, demokratikleşme anlamına gelmemektedir. Çünkü demokratikleşme, toplumsal ve siyasal kurumların demokratik teamüllere göre yerleşmesini ve benimsenmesini ifade etmektedir. Ancak çok partili hayata geçiş demokratikleşme sürecinin önemli bir parçasını oluşturmaktadır. Türkiye' de hem 1946 öncesinde hem sonrasında demokratikleşme açısından yaşanan sancıların nedenini anlamak bakımından, Türkiye'nin çok partili hayata geçişini etkileyen faktörler açıklayıcı bir komumdadır.

Bütün eksikliklerine rağmen, Türkiye'nin çok partili hayata geçişi, siyasetin ve ekonominin toplumsallaşması ve buna bağlı bir takım geleneklerin oluşması bakımından belli bir mesafenin alındığını göstermektedir. Bu yönüyle, çok partili hayata geçiş, Türkiye demokrasisi için bir milattır. Bu çalışmada, çok partili hayata geçişin demokrasinin kurum ve kurallarının yerleşmesi bakımından sahip olduğu önemden hareketle, bu sürecin belli başlı özellikleri hem tarihsel hem de analitik açıdan değerlendirilecek, bu süreçte rol oynayan dinamiklerin neler olduğu ortaya konmaya çalış1lacaktır. 


\section{TEK PARTI IKTIDARI DÖNEMINDE ÇOK PARTILI HAYATA GEÇISŞ DENEMELERI}

Siyasal modernleşme ya toplumun iç dinamiklerine bağl1 bir süreç şeklinde ya da topluma rağmen siyasal elitlerin çabası şeklinde ortaya çıkar. Batı ülkeleri dışında yer alan sonradan modernleşmiş ülkelerde siyasal modernleşme ikinci uygulamaya dayanmaktadır. $\mathrm{Bu}$ anlamda Türkiye'de mutlakiyet batılılaşmasından meşrutiyet batılılaşmasına, tek parti batılılaşmasından çok partili batılılaşmaya ve askeri rejim dönemlerindeki partisiz batılılaşmaya kadar siyasal modernleşme hareketinin temel taşıyıcı unsuru bürokratik elitler olmuştur (Çalık, 1989: 14).

Osmanlı Devleti'nde iktidarın sınırlandırılması anlamında siyasal modernleşmenin ilk örneği padişah ile dönemin ayanları arasında 1808'de imzalanan Sened-i İttifak’tır. Bu belge, Magna Carta benzeri yerel aktörlerin, hükümdarın mutlak iktidarına sınırlama getirdiği, padişahın kendi idaresindeki ayan ve ileri gelenlere karşı keyfi bir uygulamanın içinde yer almayacağ 1 hükmünü içeren bir metin hükmündedir. Siyasal modernleşme açısından asıl önemli gelişme Batılı güçlerin sempatisini kazanmaya yönelik ve Osmanlı Devleti'nin geleceğini, Avrupa Devletler Topluluğu'na girmesini temin edecek idari reformların yapılmasında gören Reşit Paşa'nın öncülüğünde 3 Kasım 1839 tarihinde ilan edilen ve bütün teb'anın can, ırz ve namusunun güvence altına alındığı, her suçlunun - gayr-i Müslümler de dahil - herkesin önünde alenen yargılanacağı benzeri ilkleri taşıyanTanzimat reformlarıdır (İnalcık, 1990:35-36; Shaw ve Shaw, 2000: 91-92). 1856'da ilan edilen Islahat Fermanı da - yine bat1l güçlerin baskısı üzerine - daha ziyade gayr-i Müslimlerin haklarını iyileştirmeye yönelik olup Tanzimat Fermanı'na, Ferman kapsamında verilmiş vaatlere eklemelerde bulunmayı içermektedir (Çavdar, 2004: 26).

"Yeni Osmanlılar"ın öncülüğünde ilk anayasanın ilanının yabancı güçleri reformları yapıyoruz algısı üzerinden - Osmanlı'nın içişlerine karışmasından alıkoyacağı umudu ile Mithat Paşa gibi devlet adamlarının çabalarıyla Türkiye tarihinin ilk parlamentosu ve Anayasası (Kanun-1 Esasi) 1876'da hayata geçti. İki meclisten oluşan (Meclis-i Mebusan ve Meclis-i Ayan) ve sadece iki dönem toplanmış parlamento 1878'de II. Abdülhamid tarafindan dağıtıldı (Yeşil, 1988: 4-5; Shaw ve Shaw, 2000: 219). Böylece I. Meşrutiyet dönemi olarak da anılan bu parlamenter dönemin ömrü çok kısa olmuştur.

Gittikçe güçlenen ve Batılı anlamda modern bir devlet olmanın özlemini çeken aydın ve Batılılaşmış bürokratik elitlerin çabası ile 31 Mart Olayı ile kısmen sekteye uğramış olsa da, II. Meşrutiyet dönemi başladı. Her ne kadar ilk seçimler I. Meşrutiyet döneminde yapılmış olsa da demokratik niteliklere uygun ilk seçimler II. Meşrutiyet döneminde kasım-Aralık 1908 yılında yapılmıştır. Bu 
seçimler Osmanlı ülkesi sathında İttahat ve Terakki Fırkası ile Ahrar Fırkası'nın siyasi mücadelesi içinde yapıld. Her düşünce çevresi ve etnik-dini grubun temsiledildiği bir seçim olmuştur (Kaan, 2008: 76-79). Ağustos 1909'da anayasanın bazı maddelerinin parlamenter rejimi kuracak şekilde değiştirilmesi ile 1909-1911 yılları arası dönem, demokratik sistemin siyasal zeminini oluşturan bir dönem olmuştur. $\mathrm{Bu}$ dönemde Mutedil Hürriyet Perveran Fırkas1, Ahali Firkası, Hizb-i Cedid Firkası ve daha sonra hemen hemen bütün muhalefet gruplarının ve partilerin İttihat ve Terakki'ye karşı, bünyesinde bir araya geldikleri Hürriyet ve İtilaf Fırkası kuruldu (Zürcher, 2005: 149-152). İttihat ve Terakki Fırkası, 1913'te vuku bulan Bab-1 Ali Baskını ile iktidarı ele geçirmiş ve Birinci Dünya Savaşı'nın başlaması ile siyasi parti mücadelesinin getirebileceği olumsuzluklar gerekçe gösterilerek çok partili siyasi yaşama son vermiştir (Haytoğlu, 1997: 47). II. Meşrutiyet döneminde yaşanan gelişmeler adeta Cumhuriyet döneminde yaşanan siyasi tartışma ve çatışmaların küçük bir örneğini oluşturmuş̧tur. 1808 Sened-i İttifak'tan II. Meşrutiyet'e kadar padişahın gücünü sınırlama ve demokratikleşme çabalarının tümü, halkın pek de içinde yer almadığı bir siyasi mücadele dönemini ifade etmektedir.

Türkiye Cumhuriyeti Devleti, Osmanlı Devleti'nin yıkıntıları üzerine kurulmuş bir cumhuriyettir. Cumhuriyet'in kurucu önderi Mustafa Kemal, daha cumhuriyetin kuruluşu öncesinde yapılan tartışmalarda, modern bir ulus devlet hayalini dile getirmiştir. Toplumsal dinamikler böyle bir proje için kendiliğinden harekete geçemeyeceğine göre, devletin bastırıcı ve ideolojik aygıtları aracılığıyla tepeden inme bir anlayış ile söz konusu projenin ancak hayata geçebileceğini savunmaktaydı. Mustafa Kemal, 6 Temmuz 1918 tarihinde yabancilar ile olan bir sohbetinde "Ben her vakit söylerim, burada bu vesile ile arz edeyim, benim elime büyük selahiyet geçerse, ben hayat-1 içtimaiyemizde arzu edilen inkılâbı bir anda bir 'coup' ile tatbik edeceğimi zannediyorum" (İnan, 1983: 43) diyerek bu konudaki kararlılı̆̆ını ifade etmiştir. Kurtuluş savaşı ve yeni kurulan devlet Mustafa Kemal'in askeri ve siyasi önderliğinde varlık bulmuş, yeni kurulan devlet Mustafa Kemal'e projelerini hayata geçirme firsatı tanımıştır.

Geleneksel değerlerle yoğrulmuş bir toplumun, hedeflenen epistemolojik kopuşu yani dini olandan seküler olana geçişi hoş karşılamayacağı aşikârdı. 1923 yılında cumhuriyeti kuran kadronun önderi Mustafa Kemal, bu tarihten başlamak üzere modern ulus devlet projesini hayata geçirmek için çok sayıda devrim yapmıştır. 3 Mart 1924 'te halifeliği kaldıran ve eğitimi birleştiren kararını, Şeyhülislamlık makamını ve Şer'iye Vekâletini kaldıran ve kadıların şeriatı uyguladıkları Şer'iye mahkemelerini ilga eden çok sayıda karar izledi. Bu tür değişiklikler, değişime kapalı geleneksel-muhafazakâr kesimleri rahatsız etti. Ayrıca temsil ettikleri değer yargıları itibariyle Mustafa Kemal'den farklı düşünen, birçoğu kurtuluş savaşından arkadaşları, kendisine muhalefet etmeye başladı (Lewis, 1996: 264). 
Mustafa Kemal'in radikal sosyal ve siyasal devrimleri, kendisine muhalif olanları harekete geçirerek 17 Kasım 1924'te Terakkiperver Cumhuriyet Fırkası ismiyle bir partinin bünyesinde bir araya getirdi. Yeni partinin liderleri arasında Mustafa Kemal' in çok yakın arkadaşları olan ve Halk Partisi'nden ayrılan Rauf Orbay, Ali Fuat Cebesoy, Refet Bele ve Kazım Karabekir ile birlikte diğer sivil ve askeri şahsiyetler vardı (Erdoğan, 2018). Partinin kurucuları, halkın iradesinin devlette egemen olması ile mevcut durumun değişeceği iddiasında idiler. Parti programının birinci maddesinde, "Türkiye Devleti halkın egemenliğine dayanan bir cumhuriyettir" denilmekteydi. Liberalizme ve halkın egemenliğine vurgu yapan programda devlet müdahalesinin en aza indirileceği ve ticaretin serbestleştirileceği ifade edilmekteydi. Bu anlamda parti liberal bir programa sahipti (Ahmad, 1995: 86; Sarıbay, 2001: 48-49). Terakkiperver Cumhuriyet Frrkası, kısa bir süre sonra Mustafa Kemal'in temsil ettiği çizgiye muhalif olan herkesin çatısı altında bir araya geldiği bir muhalefet odağına dönüştü. Bunlar arasında siyasal İslam anlayışına bağlı kişiler de vardı.

Mustafa Kemal ve onun gibi düşünenler ancak devlet eliyle gerçekleştirebileceğine inandıkları devrimler gerçekleşmeden popüler siyasal söyleme sahip bir partinin reformları gerçekleştirmenin önünde bir engel teşkil edeceği kanısındaydılar. Tam da bu süreçte Şubat 1925 'te Doğu Anadolu'da Şeyh Said'in önderlik ettiği bir isyan başladı. İsyan belli ölçüde Kürt ulusçu öğeleri içinde barındırıyorsa da, isyanın ortaya çıktığı ve geliştiği ortama daha ziyade dini öğeler hakimdi (Yeşil, 1988: 16; Ahmad, 1995: 86-87). Bu olayın dini siyasi talepleri ve karşı devrim korkularını doğruladığı kanaati güçlendi. $\mathrm{Bu}$ gelişme üzerine çıkarılan Takrir-i Sükun Yasası kapsamında, kuruluşundan yedi ay sonra, Terakkiperver Cumhuriyet Fırkası kapatıldı. Böylece muhalefet partisi, daha ete kemiğe bürünmeden varlığı son bulmuş oldu.

1925 ile 1930 yılları arasında çok sayıda köktenci sayılabilecek reform yapıldı. Kökleri tarihin derinliklerinde olan topluma hakim anlayışı radikal bir şekilde reddeden biçimsel ama hızlı olan bu değişimi toplumun özümsemesi beklenemezdi. Öte yandan, Cumhuriyet'in kuruluşundan bu yana, toplumun refah seviyesini yükseltecek ekonomik yatırımlar da gerçekleşemeyince, yığınların muhalefeti kendiliğinden oluştu. Mustafa Kemal, zor şartlarda kurulmuş Cumhuriyetin ve onun ayrılmaz bir parçası olan devrimlerin korunması gerektiğine inanıyordu. Diğer yandan, merkezi denetimin kaybedilmesine sebep olacak yığınların hoşnutsuzluğundan da korkuyordu. Bunun üzerine, yeni bir partinin kurulmasına karar verildi. Kurulacak partinin ayrıca Türkiye'nin Batı Avrupa'daki imajını düzelteceği, buna göre dış kredi ve yatırım olanăğ yaratacağı umulmaktaydı. Bunun üzerine, toplumun öfkesini dindirecek, emniyet supabı mahiyetinde, yakın arkadaşı Fethi Okyar'a Ağustos 1930'da Serbest Cumhuriyet Fırkası ismi ile bir parti kurdurdu (Çavdar, 2004: 328-329; Ahmad, 
1995: 88).Serbest Cumhuriyet Fırkası, Terakkiperver Cumhuriyet Fırkası'na göre daha az bağımsızdı ve iktidar partisine karşı daha az dikkate alınacak bir parti idi.

Kurulan yeni parti, tekrar muhalif olan liberal ve muhafazakâr kesimin ilgi odağı oldu. Fethi Okyar yurt geneline yaptı̆ğ ziyaretlerde halkın büyük ilgisi ile karşılanmış, İzmir'de kitlesel gösteriler gerçekleşmişti. Terakkiperver Cumhuriyet Fırkası'nın kuruluşu sürecinde ortaya çıkan kaygılar tekrar ortaya çıtı ve Kasım 1930'da partinin genel başkanı durumun nazikliğini gerekçe göstererek partiyi feshetti (Lewis, 1996: 280). Böylece, cumhuriyet döneminde ikinci defa çok partili hayata geçiş denemesine, gerçekleştirilen devrimlerin halk tarafindan benimsenmemiş olduğu düşünülerek, yapılan reformlardan elde edilen kazanımları kaybetmemek adına, son verildi.

Mustafa Kemal'in ölümünden sonra İsmet İnönü'nün milli şef dönemi başladı. Halk Partisi'nde otoriter eğilimli, devrimlerin zora dayanılarak tahkim edilmesi taraftarı Recep Peker'in etkisi arttı. Daha Mustafa Kemal'in iktidarı döneminde başlayan partiyi devletle özdeşleştirme anlayışı bu yeni dönemde daha da belirginleşti. Bir yandan devletin sert ve baskıcı uygulamaları diğer yandan II. Dünya Savaşı koşullarının yarattığı ekonomik dar boğaz geniş halk kitlelerini hayatından bezdirmişti.

\section{ÇOK PARTILİ HAYATA GEÇIŞİN NEDENLERI}

Türkiye'nin çok partili hayata geçişi ile ilgili yapılmış değişik tartışmalar bulunmaktadır. Bu konuda Kongar, Kemalist ideolojinin niteliğinden doğduğunu iddia ettiği demokratikleşmeye geçişin nedeni olarak başlica üç unsuru öne çıkarmaktadır. Buna göre, birinci unsur, Batı dünyasının etkisidir. Batı, Türkiye'yi kendi içine kabul etmek için demokratikleşmeyi zorunlu kılıyordu. Bask1 rejimlerinin yıkılmış olması da bunda etkilidir. İkincisi, halkın tek parti rejimi iktidarına gösterdiği tepkidir. Üçüncüsü, de o zamana kadarki devletçi uygulamaların ve "savaş ekonomisi"nin sonucu kapitalist bir zümrenin belirginleşmesidir (Kongar, 1995: 158). Bu üç unsura bir de Sovyetler Birliği'nden gelen tehdidi eklemek gerekmektedir. Buradan hareketle, çok partili hayata geçişi iç ve dış nedenler şeklinde genel bir sınıflandırmaya tabi tutmak mümkündür.

\section{Çok Partili Hayata Geçişin İç Nedenleri}

II. Dünya Savaşı'nın bittiği yıllara gelindiğinde, İsmet İnönü iktidarı büyük ölçüde halkın gözünden düşmüştü. Cumhuriyet'in kuruluşundan hemen sonra hayata geçirilen sosyal ve siyasal reformlara halk yabancıydı. Halkın hiçbir zaman bu yönde talepleri olmamıştı. Yeni kurulan modern devletin nüfuzu yine kırsal alanlarda kendi halinde yaşayan köylünün huzursuzluk kaynaklarından bir tanesi idi. Üstüne üstlük, halkın bu nefret ve yabancılaşmasını katlanır hale 
getirecek ekonomik yatırımlar da gerçekleşmiş değildi. Ayrıca II. Dünya Savaşı süresince mevcut ekonomik krizlerden de istifade ederek, 1923'lerden itibaren devlet eliyle büyütülmeye çalışılan bir burjuva sınıfı sesini yükseltmeye başlamıştı. İsmet İnönü, Aralık 1969'da mecliste yaptığı bir konuşmada “19451946 'da demokratik rejimi getirmeseydik, asıl kanlı ihtilal o zaman olacaktı ve o zaman bugünkü pek kıymetli Atatürkçüler ağızlarına geleni söyleyip, memleketi bir büyük harp badiresinden selamete çıkmış olan memleketi ayaklarıyla isyana itiyordu" (Akt. Çufalı, 2018:6) sözleriyle halkın tek parti iktidarına karşı olan tepkisini ve çok partili hayata geçişte iç kamuoyunda oluşan hassasiyeti ortaya koymaktaydı. 1940'lı yılların ortalarına doğru Kurtuluş savaşı süresince aydın, sivil-asker bürokrat, Müslüman-gayr-i müslim tüccar ve toprak sahipleri arasında süren ittifak değişik nedenlerden, özellikle de sosyo-ekonomik koşulların olumsuzluğundan dolayı, bozulmaya yüz tutmuştu.

\section{Sosyo-Ekonomik Baskılar}

1930 ile 1945 arası bütün dünya için zor yıllardı. 1929'da yaşanan Büyük Depresyon kapitalist sistemin karşılaştı̆̆ en büyük krizlerden bir tanesiydi. Krizden dolayı milyonlarca insan işsiz kaldı, ülkelerin milli gelirlerinde ciddi düşme meydana geldi. Ülkeler arası ticaret sekteye uğrarken, birçok ülke altın ve döviz kaynaklarını koruyabilmek için ithalatta kısıtlamaya gitti ve paralarını devalüe etti. Bunun sonucunda ülkelerarası ticaret hızla daraldı, işsizlik arttı ve yaşam standardı düştü (Eğilmez, 2018: 34). Bu gelişmeye eşlik eden ve 44 milyon insanın hayatını kaybetmesine sebep olan II. Dünya Savaşı ekonomik krizin etkilerini daha da derinleştirdi. Türkiye de söz konusu gelişmelerden en çok etkilenen ülkelerden bir tanesiydi. Yıllarca devam eden Balkan Savaşları, I. Dünya Savaşı ve kurtuluş savaşının sosyal ve ekonomik alanda yarattı̆̆ tahribatları bertaraf edememiş Türkiye, şimdi de bunlara ek olarak küresel etkileri olan bir savaşın sebep olduğu ekonomik dar boğaz ile karşı karşıyaydı.

Seferberlik, tarımda işgücünün çekilmesine ve ciddi üretim kaybına sebep oldu (Özcan, 2016: 39). Bu anlamda, 1945 yllına gelindiğinde Türkiye'de toplumun genel refah seviyesinde gözle görülür bir gelişme olmaması bir yana, mevcut yaşam koşulları daha da kötüleşmişti. Halkın \% 75’i hala köylerde oturmaktaydı. Okuma yazma bilme oranı \% 30 idi, hastane sayıs1 1940 yılında 154 iken, 1945'te 153'e; eczane sayıs1 1938'de 501 iken, 1945'te 483'e düşmüştü. Tahıl ve bakla üretimi 1940'tan 1945'e gelindiğinde yarı yarıya azalmıştı (Çufalı, 2018: 4). Çağdaşlaşmanın göstergesi olan su, yol ve elektrik imkanlarına kavuşmada gözle görülür bir değişiklik yoktu. 1953'te dahi elektriğe kavuşmuş köy sayısı sadece 10 idi(Zürcher. 2005:300).

Sanayi yatırımları, 1948 endeksi 100 kabul edilirse, 1933'te 9, 1934'te 29, 1936 'da 40, 1938'de 67, 1939'da 127'dir. Ancak 1940 yilında oran 59'a 1946'da 
ise 6'ya düşecektir. Tarım sektöründe durum çok farklı değildir. 1948 endeksi 100 alınırsa tarım sektöründe kamu yatırımları 1930 'da 44, 1933'te 25, 1939'da 281,1940 'ta 313'tür. Ancak 1944'e gelindiğinde oran 88'e düşmektedir. Bu tablo Türkiye ekonomisinin dünya koşullarına ne kadar bağımlı olduğunu göstermektedir (Kahraman, 2010: 145-146). Enflasyon askeri harcamaların etkisi ile adeta şahlandı. 1938 endeksi 100 kabul edilirse, Ağustos 1946'da fiyatlar 386,8 ve Eylülde 412,9'a yükseldi (Ahmad, 2015: 38). Yine bu yıllarda buğdayın resmi fiyatı 13,5 kuruş iken, serbest fiyatı 30, 40, 50, 70 hatta 100 kuruşa doğru çıkmaktaydı (Aydemir, 2016: 345). Ekonomideki bu genel kötü gidişatta II. Dünya Savaşı'nın getirdiği olumsuzlukların etkisi büyük olmakla birlikte [Örneğin 1940-1949 yılları arası dönemde Türkiye'nin büyüme oranı \% -0,9 olsa da, 1923-1929 döneminde büyüme oranı \% 9,4, 1930-1939 döneminde \% 6,0'dır (Eğilmez, 2018: 154). Ortalama ahalinin gözünde yaşanan olumsuzlukların müsebbibi mevcut bürokratik devlet iktidarıyd.

Savaş yıllarında ortaya çıkan ekonomik yük daha çok küçük ve orta köylülük ile ücretli kesim üzerine bindirildi. Vergilerin köylüler için getirdiği ağır yük ve buna eşlik eden köylülerin yoksulluğu, bürokrasinin yozlaşması ve hükümetin zayıflığı, sorunları patlama noktasına taşımıştı. Altı liralık ödenmeyen yol parası ${ }^{2}$ için bile köylüler madenlerde çalıştırılmaktaydı (Haytoğlu, 1997: 51). Toprak Mahsulleri Vergisi, köylülük için yeni mali yük getirdi. Bu dönemde, köylülük henüz siyasal karar alma mekanizmasının bir parçası değildi. Köylünün siyasal bir aktör olmadığı bu dönemde siyasal iktidar için ekonomik öncelik taşıması beklenemezdi. Jandarma ve vergi tahsildarlarının baskısı ve keyfi uygulamaları, laik uygulamaların devlet ile uyrukları arasındaki en önemli ideolojik bağı koparması onları iyice devlete ve iktidara yabancılaştırdı. 1936 yılında hazırlanan 3008 sayılı İş Kanunu Musolini dönemi İtalya'sının kanunları emsal alınarak hazırlandığından işçi sorunları totaliter bir anlayış ile düzenlenmişti. İşçi sınıfi, fazla mesai angaryası, istifa haklarını kullanamama bağlamında işyerine bağlı kalma; sendika kurma, toplu pazarlık ve sözleşme yapma hakkının olmaması; Milli Korunma Kanunu'nun mükellefiyetleri gibi olumsuzluklardan dolayı artık iktidarın değiş̧mesi gerektiğini düşünmekteydi (Çavdar, 2004. 447; Zürcher, 2005: 300; Karpat, 2017: 198). Artan enflasyon, sabit ücretli memurlar1 da ekonomik açıdan dar boğazın içine sürükledi. Modernleşme projesinin bir parçası olan memur, Kemalist ideoloji ile terbiye edilmiş olmakla beraber iktidardan soğumuştu.

\footnotetext{
${ }^{2}$ Yol yapım çalışmalarına kaynak sağlamak için Tanzimat döneminde sistemleştirilen, Cumhuriyet döneminde iki katına çıkarılan, bedeni ve nakdiödenebilen, bedeni olarak y1lda 6-12 ortalama iş gününe sahip kişilerin görebileceği iş biçiminde düzenlenmiş Yol Vergisi olarak bilinen bir vergi çeşididir (Özdemir, 2013: 215-218).
} 
Varlık Vergisi ve Milli Korunma Kanunu çerçevesindeki uygulamalar ve devlet işletmelerinden kaynaklı oluşan haksız rekabet, liberal ekonomi beklentisi olan sermaye gruplarını; Köy Enstitüleri uygulaması ve Çiftçiyi Topraklandırma Kanunu kapsamında toprak reformu girişimleri de toprak sahiplerini Cumhuriyet Halk Partisi (CHP) ve iktidar çevrelerinden uzaklaştırmaktaydı, Bunun yanı sıra, 20 Aralık 1940 ile 1 Haziran 1945 tarihleri arasında yürürlükte kalan Olağanüstü Hal Kanunu, devam eden ekonomik olumsuzluklara eşlik eden devletin ceberut yüzüydü (Özcan, 2016: 39-40; Karpat, 2012: 67). Modern bir ulus inşa etmek üzere yapılan düzenlemeler kapsamında Arap alfabesinden Latin alfabesine geçiş, kılık kıyafette yapılan değişiklikler, halifeliğin kaldırılması, laikliğin anayasaya sokulması ve popüler dinin ifade biçimlerinin bastırılması toplumun geniş kesimi tarafından rahatsızlık uyandırmışıır. Böylece devlet ile halk arasındaki en önemli ideolojik bağ da kopmuş oluyordu (Zürcher, 2005: 300). Timur, DP'nin kuruluşu ile ilgili, savaş yıllarında uygulanan politikaların halk tabanında bir muhalefet ortamını yaratmış olsa da bir muhalefet partisinin kurulması teşebbüsünün yönetici kadroların girişimi olduğunu ifade etmektedir (Timur, 1991: 25). Buradan hareketle, Bu yaşananlar, bütün toplumsal kesimleri iktidardan uzaklaştırmakla birlikte, toplumun \%83'ünün köylük yerde yaşadığ11945'li yıllarda (Karpat, 2017: 188), halkın iktidar değişikliği talebini bir demokrasi isteği şeklinde düşünmemek gerekmektedir. Bu anlamda, halkın çok partili hayata dayanan demokratik bir sistemi talep etmekten ziyade kendilerine daha iyi davranacak bir iktidar talebinde oldukları söylenebilir.

\section{Bazı Vergi Uygulamaları ve Çıkarılan Kanunlara Karşı Oluşan Tepki}

II. Dünya Savaşı'nın etkisiyle ekonominin daha da kötüleşmesi üzerine devlet derin toplumsal etkiler yaratacak kararlar aldı. Bunların bazıları Varlık Vergisi, Çiftçiyi Topraklandırma Kanunu, Toprak Mahsulleri Vergisi, Milli Korunma Kanunu, Polis Yetkileri Yasas1, Basın Yasas1, Yol Vergisi ve Fiyat Murakabe Komisyonları'dır. Bu kararlar belli ölçüde dönemin ekonomik koşullarının bir dayatması şeklinde değerlendirilebilir olmakla birlikte, uygulamada birçok keyfiliği de içinde barındırdığı - özellikle jandarma ve vergi tahsildarlarının uygulamalar1 - söylenebilir.

11 Kasım 1942 tarihli Varlık Vergisi’nin görünürdeki amacı, II. Dünya Savaşı koşullarında enflasyonist ortamdan yararlanarak büyük servet biriktiren sermaye çevrelerinin biriktirdiği servetin bir bölümünü devlete aktarmaktı (Kepenek, 2014: 64). Ancak "Bu verginin uygulanış biçimi hükümetin asıl amacının, resmen açılanmasa da, İstanbul ve İzmir'deki gayr-i müslim tacir ve sanayicilerin Türkiye ekonomisindeki güçlerini kırmak ve Müslüman-Türk iş adamlarına, özellikle dış ticaret sektöründe yer sağlamak olduğunu açığa çıkardı” (Tezel, 2015: 313) yönünde güçlü bir kanaatin oluşmasına sebep oldu. Verginin uygulanması yasal bir mantık içermemekteydi. Belirlenen vergi miktarını 
karşılayamayanlar, tam bir angarya mantığına uygun bir şekilde, Doğu Anadolu'daki çalışma kamplarına gönderilerek yol yapım işlerinde istihdam edilmekteydi. Verginin muhatapları Müslüman, gayr-i müslim, Ecnebi ve Dönme şeklinde sınıflandırılmış olup, dönmeler, Müslümanların iki katı vergi ödemekteyken, gayr-i müslimler ise on katı ödemekteydi. Örneğin İstanbul'da toplanan verginin \%65'i gayr-i müslimlerden toplanmıştı. Ocak 1943'ün başlarında basın, vergisini ödemeyen mükelleflerin adlarını ve ödeyecekleri verginin miktarını yayınlamaya başladı. Bunların yol yapımında çalıştırılmak üzere Aşkale'ye gönderilecekleri bildirilmekteydi. Otuz iki kişilik ilk kafile 27 Ocak'ta İstanbul'dan Aşkale'ye hareket etti (Lewis, 1996: 297-298).

Varlık Vergisi, CHP'li bürokrat kökenli yönetici kadro ile varlıklı sınıfın ilişkilerini büyük ölçüde zedeledi. Gayr-i müslimleri hedef alan verginin uygulanmasında bazı Türkler karlı çıkmış olsa da, vergi Müslüman-Türkler’i de korkuttu. Siyasi iktidarın zengin gayr-i müslimleri ezen bu vergi uygulamas1, yarın kendilerini de bulacağı korkusuna kapılan Müslüman-Türk tüccar, sanayici ve büyük toprak sahiplerinin siyasal iktidardan uzaklaşmasına sebep oldu.

Hükümetin tepki toplayan uygulamalarından bir tanesi de Çiftçiyi Topraklandırma Kanunu'dur. Çiftçiyi Topraklandırma Kanunu, hükümetin feodalite benzeri bir yapı olan "ağalık sistemi"nde bağımlılık ilişkilerini ifade eden topraksız yarıcı, ortakçı ve marabalarca işlenen arazi mülklerini tasfiye etme isteğini ortaya çıkarmaktaydı. Buna göre Kanun, devlet arazilerini, tarıma elverişli hale getirilmiş arazileri, dini vakıflara ait arazileri, mülkiyeti belli olmayan arazileri ve 500 dönümden fazla toprağı olanlara ait arazileri topraksız, az topraklılar ile çiftçilik yapmak isteyenlere geçimlerine olanak tanıyacak büyüklükte dağıtmayı öngörmekteydi (Tezel, 2015: 460; Zürcher, 2005: 305). Çiftçiyi Topraklandırma Kanunu bağlamında İsmet İnönü'nün "batakçı toprak ağasının kökünü kazıyacağım" (Aydemir, 2016: 347) sözü sembolik anlamda Kemalist iktidar çevreleri ile büyük toprak ağaları arasında kurtuluş savaşı sürecince devam eden ittifakın son bulduğunun göstergesiydi. İnönü, II. Dünya Savaşı'nın zor ekonomik şartlarında bunların istifçilik, karaborsacılık ve vurgunculuk yaptıklarına inanmaktaydı. Kanun, daha sonra pek çok değişikliğe uğrayarak, uygulanması yönünde sınırlamalar getirilmiş, devletin elindeki bir kısım toprakların, özellikle meraların dağıtılmasından öteye gidememiştir (Baysal, 1984: 460).

Köylü kesimi Kemalist iktidara karşı öfkelendirecek ve köylüyü hükümet ve hükümetin kendisi ile bütünleştiği devletten biraz daha uzaklaştıracak bir diğer uygulama da Toprak Mahsulleri Vergisi'dir. Toprak Mahsulleri Vergisi, Cumhuriyet - köylü uzlaşmasının en önemli noktalardan bir tanesi olan kaldırılmış aşar vergisinin tekrar geri getirilmesi olarak değerlendirilmektedir. Halkın devlet eliyle daha da yoksullaştırılması anlamına gelen bu vergi, topraktan 
aldığı ürün ile kendisini geçindirmeye çalışan köylü halka salınmıştır. Ödeyemeyen köylünün yol yapım işlerinde çalıştırılacağı bu vergi, belli tarım kalemlerinde ürün olarak ödenecekti (Kahraman, 2010: 170). 4 Haziran 1943’te kanunlaşan Toprak Mahsulleri Vergisi, ilk etapta savaş sırasında enflasyonla mücadele için toprak ürünlerini suni yoldan düşük fiyatlandırma ve yüksek kazanç sahibi olanlardan vergi alınmasını hedef almış olsa da, uygulamada büyük ve küçük çiftçi ayırımı gözetmeksizin bütün çiftçilerden alınmıştır. Daha da ötesi, verginin yükünü esas olarak küçük çiftçi ve köylüler çekmiştir (Akandere, 1998: 168-169; Zürcher, 2005: 301). Köyün dingin ve kendi halindeki yaşamına alış1k köylü, alışık olmadığı modern devletin nüfuzu karşısında kendini çok aciz hissetmiş, buna anlam verememiştir. Günümüzde hala o günlerden kalma, devlettoplum yabancılaşmasına büyük etkisi olmuş anekdotlar anlatılmaktadır.

Benzer özelliklere sahip 18 Ocak 1940 tarihinde çıkarılan Milli Korunma Kanunu, ekonomik sıkıntıların üstesinden gelmek adına, piyasaya mal temin etmek ve fiyatları kontrol etmek için insanları değişik işlerde, özellikle de madenlerde, çalıştırmak üzere hükümete olağanüstü yetkiler tanımış çok geniş kapsamlı bir düzenlemedir (Akıncı ve Usta, 2015: 50). Özel girişimin bütünüyle devlet denetimine girdiği, toprak ürünlerinin devlete satılma mecburiyetini getiren bu kanunla hükümet, ekonomiyi düzenlemede çok geniş yetkilere sahip olmuştur. Ayrıca temel hak ve hürriyetleri sınırlandırıcı kararlar yürürlüğge konulmuştur. Örneğin hükümet, ihtiyaç durumunda çiftçilik yapmaya elverişli kadın ve erkekleri devlete ya da kişiye ait ziraat işlerinde ücretli olarak çalıştırabilecekti. Kanun sınıfsal açıdan işçiler ile köylüler aleyhine sonuçlar doğurmuştur. İşçiler, düşük ücretlerle çalıştırılarak ve fazla mesai yaptırılarak zor durumda bırakılmıştır. Köylüler ise ürünlerine el koyan hükümetin belirlediği serbest piyasa fiyatlarından daha düşük fiyatlarla ürünü satmak zorunda kalmıştır (Koçak, 2017: 373-405; Karpat, 2017: 192-193). Devletin CHP iktidarı şahsında hayata geçirdiği söz konusu uygulamalar, varlıklı-yoksul ayırımı olmaksızın bütün toplumsal çevrelerin tepkisi ile karşılaşmış, mevcut iktidarın meşruiyetini olumsuz yönde etkilemiştir.

\section{Sinıfsal Etkenler}

Tek parti iktidarının üzerinde durduğu konulardan bir tanesi milli bir burjuvanın yetiştirilmesidir. Çünkü ulus fikri ancak güçlü bir orta sınıfın varlığı ile mümkün olabilir. Bu çerçevede, ilk sanayileşme adımları atılmış, azınlıkların piyasadaki etkisi azaltılmaya - Varlık Vergisi uygulamasında olduğu gibi çalışılmıştır. 1940'lı yılların sonlarına doğru gelindiğinde piyasada etkisi hissedilebilecek bir burjuva sınıfı vücut bulmuştur (Örmeci, 2008: 62). Tarih boyunca ekonomik gücü elinde tutan sınıf aynı zamanda iktidardan da pay almak istemiştir. Avrupa'da aristokratların kralların iktidarını sınırlamaları, burjuva sınıfının İngiltere ve Fransa'da yaptıkları devrim bunun örnekleridir. Burjuva 
sınıfı, sınıfsal doğası gereği liberal değerleri ve bu bağlamda devlet gücünün hem piyasada hem siyasette azaltılmasını savunur. Türkiye'de çok partili hayata geçiş sürecinde sermaye gruplarının tek parti iktidarından rahatsızlı̆ıını ve Demokrat Parti'nin (DP) etrafında kümelenmelerini bir ölçüde bu açıdan değerlendirmek gerekmektedir.

II. Dünya Savaşı, en çok iki sınıfa yaramıştı. Büyük çiftçiler ve İstanbul tüccar ve komisyoncuları. Savaş'ın yarattığ kıtlık ortamı ve ihtiyaç duyulan zorunlu tüketim maddelerinin piyasadaki azlığı spekülatörlerin karlarına kar katmaktaydı. Büyük çiftçiler, tarım fiyatlarının aşırı yükselmesinden büyük kazanç sağlamıştı. Örneğin savaş sonunda bir milletvekili mecliste yaptığ 1 konuşmada "sayılarını kimse bilmez ama bizde de 30-40 bin kadar savaş zengini milyoner türemiştir" (Timur, 1991: 21) diyerek bu spekülatörlere dikkat çekmiştir. İstanbul tüccar ve komisyoncuları hem yerli ihracat maddelerinin aşırı değerlenmesini hem de temel zorunlu ithal mallarının kıtlığını çıkarına uygun bir şekilde kötüye kullanmıştı. Çiftçilerin tümü Müslüman ahaliden iken, tüccarların büyük bir kısmı Rum, Yahudi ve Ermeni idi (Lewis, 1996: 296).

"Savaşın zenginleri” olarak isimlendirilen bu grup, genel olarak, büyükşehirlerin tüccar kesimi ile yüksek memurlardan oluşmaktadır. 1941-1942 yıllarında yaklaşık 2000 yeni firmanın İstanbul Ticaret Odası'na kayıt yaptırması savaş zenginleri sınıfının bir göstergesi kabul edilmektedir (Akıncı ve Usta, 2015: 48). Kurtuluş savaşı ve tek parti iktidarı süresince asker-sivil bürokrat seçkinler ile toprak sahipleri ve kentli sınıflar arasında kurulmuş bir ittifak vardı. $\mathrm{Bu}$ anlamda, CHP iktidarı bir koalisyonlar ittifakı idi. 1940'lı yılların ortalarından itibaren bu ittifak aşınmaya başladı. Hükümetin, asıl hedefi gayr-i müslim iş çevreleri olsa da Varlık Vergisi, Türk burjuvazisinin genelinde huzursuzluğa neden olmuştu. Bu vergi, Kemalist rejimin sermaye çevrelerinin çıkarlarının tam güvenilir bir destekleyicisi olmadığını göstermiştir. Bunun yansıra, biriktirdiği sermaye ile konumunu güçlendirmiş yerli burjuvazi, artık iktidardan pay almak istemekteydi (Zürcher, 2005: 301; Timur, 1991: 18-22; Ahmad, 1995: 148). Türk sisteminin batı sistemine entegre olması yönünde $A B D$ ve Avrupa ülkelerinin baskısı bu çevreleri cesaretlendirmekteydi.

Hükümetin enflasyonla mücadele için çiftçinin ürününü suni yoldan düşük fiyatlandırması, Toprak Mahsulleri Vergisi ve özellikle çıkarılan Çiftçiyi Topraklandırma Kanunu, Osmanlı Devleti'nden itibaren gelişerek Cumhuriyet döneminde tam olarak belirginleşen büyük toprak sahibi çiftçilerin tepkisi ile karşılaşmıştır. Örneğin Türkiye siyasetinde kalıcı etkilere sebep olacak Çiftçiyi Topraklandırma Kanun tasarısı, mecliste büyük tartışmalara yol açtı. Mecliste yürütülen tartışmalarda Adnan Menderes, Cavit Oral, Emin Sazak ve Halil Menteşe gibi büyük toprak sahipleri ile başka çok sayıda milletvekili tasarıya büyük muhalefet gösterdiler. Büyük arazi sahibi kesimin çıkarlarını tehdit eden 
bu yasa Türkiye siyasetinde derin etkiler yarattı. Tasarıya muhalefet eden Adnan Menderes, Fevzi Lütfi Karaosmanoğlu, Emin Sazak ve Halil Menteşe gibi büyük arazi sahipleri kısa bir süre sonra CHP'den ayrılacak ve Demokrat Parti'nin kuruluşuna önderlik edeceklerdir (https://www.ulusal.com.tr). Büyük ve orta sınıf toprak sahipleri Topraklandırma Yasası görüşmelerinden kısa bir süre sonra kurulacak Demokrat Parti'ye kırsalda gösterdikleri kitlesel destek ile tepkilerini ortaya koydular.

Mayıs-Haziran 1939'daki CHP'nin Beşinci Büyük Kurultay'ında hükümetin politikalarını ve CHP'yi eleştirecek bir "Bağımsız Grup"un kurulmasına izin verilmişti (Timur, 1991: 10; Ahmad, 1995: 102). Ancak bu çok tatmin edici değildi. Cumhuriyet' in kuruluşundan o güne kadar - devlet desteği ile - sermaye biriktirmiş bir burjuva sınıfı şekillenmeye başlamıştı. Bu sınıf artık çıkarlarını başka bir yerde konumlandırmaktaydı.

Siyasetçi-işadamı, bankacı Celal Bayar, pamuk üreticisi, toprak sahibi Adnan Menderes, tarih profesörü Fuat Köprülü ve bürokrat Refik Koraltan 7 Haziran 1945 tarihinde CHP meclis grubuna çoğulcu demokratik bir sisteme geçilmesini öneren bir önerge vermişlerdir. Türkiye siyaset tarihine "dörtlü takrir" olarak geçen önerge ile milli egemenlik ilkesinin hayata geçmesi istenmiş, parti işleyişinin demokratik teamüllere göre olması, hükümetin TBMM tarafindan denetlenmesi gerektiği talebinde bulunulmuştur. Önerge, CHP grubu tarafindan reddedilmekle birlikte, Menderes, hükümete karşı sert tutumunu Birleşmiş Milletler Antlaşması'nın onaylanması için yapılan görüşmelerde sürdürmüş, bir an önce tek parti rejiminden kurtularak, Türkiye'nin uluslararası düzeyde girdiği bu taahhüde uygun bir şekilde sistemini demokratik teamüller doğrultusunda şekillendirmesi gerektiğini ifade etmiştir (Kahraman, 2010: 197; Zürcher, 2005: 306; Erdoğan, 2018).

\section{Çok Partili Hayata Geçişin Dış Nedenleri}

Türkiye'nin çok partili hayata geçişin iç nedenlerinin belirleyiciliğini dikkate almak gerekmekle birlikte, asıl belirleyici unsurun diş nedenler, özellikle de Sovyet tehdidi, olduğu konusunda yaygın bir kanaat vardır (Ahmad, 1995: 148, Kahraman, 2010: 192, Kara-İncioğlu, 2007:254).San Francisco Konferansı'na katılacak Feridun Cemal Erkin'e İsmet İnönü'nün “Amerikalılar çok partili demokrasiyi ne zaman kuracağımızı sorabilirler (...) Şöyle cevap verirsiniz (...) Savaş bitince bu amacı gerçekleştirmek Cumhurbaşkanı'nın en aziz arzusudur" (Akt. Kahraman, 2010: 191) şeklindeki ABD'yi memnun etme çabası taşıyan mesajı dış etkenlerin, özellikle de Sovyet tehdidinin, çok partili hayata geçişte oynadığı rolü ortaya koymada açıklayıcı olabilir.

\section{Popülerleşen Liberal Değerler ve Batı ile İlişkileri Geliştirme İhtiyacı}


II. Dünya Savaşı'nın sonuçları uluslararası sistemde köklü bir değişiklik yaratmıştır. Savaşın sonucu, yalnızca Avrupa'da hegemonik bir güç olmak isteyen Almanya ve İtalya ile Uzakdoğu'daki ideolojik partnerleri Japonya'daki faşist rejimin yıkılması anlamına gelmemekteydi, aynı zamanda demokratik rejimlerin galibiyetini ifade etmekteydi. Savaşın sonunda tek partili rejimler gözden düşmüş, kapitalist ekonomik düzene dayanan serbest seçimli demokratik sistemler öne çıkmıştır. Dünyada bu gelişmeler olurken Türkiye ekonomisi can çekişmekteydi. Devlet ulus kimliğini inşa etmek için kendi eli ile bir burjuva yaratmaya başlamış, ancak sermaye gruplarının isteksizliği ve kaynaklarının kıt olması nedeniyle proje tam olarak hayata geçirilememişti (Keyder, 2005: 32). Toplumun genel refah seviyesi çok düşüktü. Devlet, Savaş sonrası uluslararası sistemde ortaya çıkan bu yeni durumu ülke ekonomisini kalkındırmak adına bir avantaja dönüştürmek istemekteydi.

4-11 Şubat 1945 'te galip güçlerin (ABD, SSCB, İngiltere) düzenlediği Yalta Konferansı'nda savaş sonrasında kurulacak düzen tartışılmış ve yayınlanan "Kurtarılan Avrupa Hakkında Demeç"te Avrupa'da, özellikle de Nazi Almanya'sı uydusu olan ülkelerde, demokratik sistemlerin kurulacağı deklare edilmişti. Türkiye kurulacak bu yeni dünya düzeninin bir parçası olmak ve bir bakıma bu değerlerin temsilciliğini yapacak Birleşmiş Milletler'in bir üyesi olmak istemekteydi. Bunun üzerine, Türkiye 23 Şubat 1945'te Almanya ve İtalya'ya savaş ilan etti vel Ocak 1942 tarihli “Birleşmiş Milletler Demeci'ni imzaladı [Armaoğlu, (t.y.): 401; Çufalı, 2018: 2]. Türkiye üzerinde öteden beri hesapları olan Sovyet Rusya'nın 1945 Kasım'ında süresi dolacak olan 1925 yılına ait Dostluk ve Saldırmazlık Antlaşması'nı verdiği nota ile tek taraflı iptal etmesi, Birleşmiş Milletleri Türkiye için daha da önemli kılmaktaydı. 26 Haziran 1945’te Türkiye Birleşmiş Milletler Anayasası'nı demokrasi yolundaki galip devletlerle imzaladı (Yeşil, 1988: 55). ABD ve Batı'ya yanaşmasının bir devamı olarak Nisan 1949'da kurulan NATO'ya Türkiye 1952'de katıldı. Türkiye, bunlara ek olarak Avrupa ile ilişkilerini daha da güçlendirmek için 1949 yilında Avrupa Konseyine üye oldu (Akşin, 2012: 240). Batı dünyasına bu şekilde yanaşmayı, aslında kapitalist dünyanın değerlerini prensipte benimsemiş olmanın bir yansıması olarak görmekten ziyade, içerdeki ekonomik sıkıntıların tazyiki ve dış politikada bazı gelişmelerin Türkiye'nin önüne koyduğu bir zorunluluk olarak değerlendirmek gerekmektedir. Batı dünyasına yanaşan aynı çevrelerin, daha yakın bir zamanda devlet ile siyasal partiyi bütünleştirme politikaları Batı değerleri ile kurdukları ilişkinin, ilkesel bir duruştan ziyade, şartların doğurduğu bir zorunluluk olduğu kanaatini oluşturmaktadır.

II. Dünya Savaşı süresince CHP iktidarı, pragmatik bir dış politika izlemiştir. Türkiye koşullara göre Almanya'ya yanaştığı gibi Sovyetler'e ve ABD ile Batı'ya da yanaşmıştır. CHP iktidarının temel amacı şu ya da bu ideolojiye angaje 
olmaktan ziyade yeni kurulan devletin temel projesi olan modern bir ulus devlet kimliğine ulaşabilmekti.

II. Dünya Savaşı sonrası Sovyetler Birliği' nin komünizmi yayma girişimleri karşısında ABD küresel düzeyde çıkarlarını korumak ve temsil ettiği değerleri yaşatmak için diş politikada etkin olmaya karar verdi. Başkan Truman' dan ismini alan Truman Doktrini dış politikadaki bu radikal değişimin başlangıcını temsil eder. 12 Mart 1947 'de ortaya atılan Truman Doktrini, Sovyetler Birliği'nin tehdidi altındaki ülkelere - özellikle Türkiye ve Yunanistan’a - mali yardım yapılmasını öngörmekteydi [Armaoğlu, (t.y.): 443]. Truman 7 Ocak 1948 tarihli Kongre'de yaptığı konuşmada “Türkiye ve Yunanistan'a yabancı baskısına karşı tamamiyetlerini muhafaza için yardım etmekteyiz" (Yeşil, 1988: 134) diyerek bu yardımı deklare etmekteydi. 1945-1946 yıllarında ABD, Avrupa ekonomisini kalkındırmak için 15 milyar dolar yardım yapmış, ancak yardımların çoğu ithalat için kullanıldığından pek verimli olmamıştı. Bunun üzerine $A B D$ Dışişleri Bakanı George Marshall 5 Haziran 1947 günü Harvard Üniversitesi’nde yaptı̆̆ konuşmada, Avrupa ülkelerinin kendileri arasında ekonomik işbirliği yapmaları gerektiğini, bu genel işbirliği sonunda bir açık ortaya çıkarsa Amerika'nın bu açı̆̆1 kapatması gerektiğini söylemişti. [Armaoğlu, (t.y.): 443-444]. ABD Dışişleri Bakanı'nın bu açıklamasından sonra Avrupa ülkelerine yapılan yardımlar Marshall Planı çerçevesinde değerlendirilmiş̧tir.

Marshall Planı doğrultusunda Türkiye'ye hem hibe hem de borç şeklinde parasal destekte bulunuldu. Planı'nın iki temel amacı vardı. Birincisi, II. Dünya Savaşı'nda çökmüş olan Avrupa ülkelerinin ekonomilerinin toparlanmasına yardımcı olmak; ikincisi, kapitalist dünyanın gittikçe bir tehlike olarak görmeye başladığı komünizm ve Sovyet yayılmacılığını önlemekti (Eğilmez, 2018: 142). Türkiye, ABD ve Avrupa ülkeleri ile ilişkilerini derinleştirmek adına, 1947'de Türkiye-ABD Askeri Yardım Antlaşması imzalandı. Marshall yardımları paralelinde kredilerin koordinasyonu için 16 Nisan 1948'de kurulan Avrupa İktisadi İşbirliği Teşkilatı'na Türkiye kurucu üye olarak katıldı (Yeşil, 1988: 137). 4 Temmuz 1948 tarihinde Türkiye-ABD Ekonomik İşbirliği Antlaşması'nın imzalanması ile başlayan Marshall Planı bünyesinde örneğin 1947-1949 yılları arasında ABD Türkiye'ye yaklaşık 150 milyon dolar yardımda bulunmuştur (Tuna, 2007: 92). Gelen paranın önemli bir kısmının tarımın modernizasyonunda kullanıldığı düşünüldüğünde, bu paranın ekonomiye önemli katkılarda bulunduğu görülmektedir. Örneğin Türkiye' de traktör sayıs1 1945 'te 1.156 iken, 1950 'ye gelindiğinde sayı 16.585 'i bulmaktadır. İşlenen arazilerin miktarı da aynı oranda artış göstermiştir (Kepenek, 2014: 104-105).

ABD ve müttefikleri, temsil ettikleri değerler olan ekonomide serbest piyasa ve siyasette çok partili hayat modelini her ülkenin benimsemesi gereken ideal değerler olarak görmekteydi. Devlet radyosunda yapılan bir konuşmada 
Amerikalı devlet ve siyaset adamlarının görüşleri şu şekilde aktarılmaktaydı: "Kurtulan Avrupa memleketleri, kendilerine uygun gelen demokratik müesseseleri... seçeceklerdir. Şayet herhangi bir memlekette bir şahsın yahut zümrenin diktatörce temayüller gösterdiği tespit edilecek olursa, üç büyük devlet ile diğer devletler, buna mani olacaklardır" (Kara-İncioğlu, 2007: 255). Nitekim savaş sonrasında, ABD İnönü ve CHP'ye "çok partili hayata geçiş" ve "komünizm ile mücadele" konularında baskı uygulamış, ABD Kongresinde Truman Doktrini konuşulurken Ohio temsilcisi CHP yönetimini "küstah bir diktatörlük" şeklinde itham etmiştir. Yanı sıra ABD'nin sermaye grupları da bu yönde CHP'ye baskı uygulamaktaydı. Bu doğrultuda CHP iktidarı 1945'ten sonra üç politikayı hayata geçirdi: İktisadi liberalleşme, siyasi liberalleşme ve komünizm ile mücadele (Sancaktar, 2012: 51-52). Dolayısıyla bu değerler doğrultusunda özellikle de $\mathrm{ABD}$, Türk siyasal sisteminin piyasa ekonomisine ve buna bağlı çok partili hayata geçmesi için baskı uygulamaktaydı. Daha geniş anlamda, uluslararası ortam siyasal iktidarı siyasal liberalleşmeye zorlamaktaydı (Ahmad, 2015: 401; Koçak, 2017: 560).

Türkiye, ABD ve Bat i ile geliştirdiği ekonomik ve askeri ilişkilerle bir yandan, Sovyet tehdidinden kurtulurken, diğer yandan ekonomisini kalkındıracak teknolojiyi, özellikle tarımda, transfer etti. Örneğin, Akşin'e göre İnönü'nün liberal siyasete geçiş kararı almasının baş nedeni bütünsel kalkınma anlayışıdır. Hiçbir alanda Avrupa'dan geri kalmak istemeyen Türkiye'nin Avrupa'daki kalkınmanın bir parçası olmak için onların siyasal değerlerine de ayak uydurması gerekmekteydi (Akşin, 2012: 140). Alınan bu kararın ülkenin sosyal ve ekonomik hayat üzerindeki etkisi daha sonra görülecektir. Nitekim ABD’nin nakdi parasal desteği ve teknoloji transferinin Türkiye ekonomisi üzerindeki etkisi 1950 sonras1 Menderes iktidarı döneminde çok bariz bir şekilde hissedilecektir.

\section{Artan Sovyetler Birliği Tehdidi}

Türkiye'nin Sovyetler Birliği ile ilişkileri 1930'ların ortalarına kadar gayet iyi gitmiştir. Türk-Sovyet ilişkilerinde yol ayırımına 1936-1939 arası dönemde gelinmiştir. Türkiye, SSCB ile ilişkilerinde genelde Batı dünyası ile ilişkilerini temel almış, Sovyetler Birliği'ni Batı'ya karşı dengeleyici bir unsur olarak görmüştür (Sönmezoğlu, 2012: 882). Dünya savaş1 iki grup arasında gerçekleşmişti. Bir tarafta İngiltere, Fransa, Sovyetler Birliği, ABD ve Çin'den oluşan müttefik güçler; diğer tarafta ise Almanya, İtalya ve Japonya'dan oluşan mihver kuvvetleri vardı. Savaş, müttefik güçlerin zaferi ile sonuçlandı. Ancak müttefik güçler de kendi içinde homojen bir grup değildi. Bir tarafta, SSCB'nin başını çektiği, sosyalizmi temsil eden blok; diğer tarafta ABD'nin öncülük ettiği kapitalist blok vardı. Savaş sonrası bu ikilik iki kutuplu bir dünya ile sonuçlandı. 
1925’te iki ülke arasında imzalanan Türkiye-SSCB Dostluk ve Tarafsızlık Antlaşması'na göre iki ülkeden birine saldırı durumunda diğeri tarafsız kalacaktı, iki ülke birbirine saldırmayacaktı. Ayrıca birbirlerine yöneltilen ittifak ve siyasi antlaşmalara da katılmayacaktı. 1925 Dostluk ve Tarafsızlık Antlaşması'nın süresini uzatan 1929 Protokolü ise,Türkiye'yi rahatsız edecek şekilde, boğazlarda Türk egemenlik yetkilerine sınırlama getirmiş, Türkiye'yi bu konuda Sovyetler Birliği'ne bağımlı hale getirmişti. SSCB'nin 1936 Montrö Boğazlar Sözleşmesi görüşmelerinden istediğini alamaması, Ağustos 1939'da Sovyet-Alman Saldırmazlık Paktı'nın imzalanması ilişkileri olumsuz etkileyen diğer konulardı (İşyar, 2009: 689-692). II. Dünya Savaş’ı iki ülke arası ilişkileri olumsuz etkiledi. Sovyetler, Savaş süresince Türkiye'nin tarafsız kalmasından rahatsız olmuştu.

II. Dünya Savaşı'nın bitmesi ile Türk-Sovyet ilişkilerinde yeni bir aşamaya geçilmiştir. Savaş’tan güçlenerek çıkan SSCB, Türkiye ile ilişkilerini Batı'nın etkisinden kurtararak tek başına yönlendirmek istemiş, Türkiye ise bunu güvenlik tehdidi olarak algılamıştır(İ̧syar, 2009: 688-689).

İki savaş arası dönemde Türkiye ile Sovyetler Birliği arasındaki ilişkiler - tam bir güvene dayalı olmazsa da - karşılıklı saygı zemininde ilerlediği söylenebilir (Sönmezoğlu, 2012: 884). Ancak Sovyetler Birliği ile Türkiye arasında kurtuluş savaşı süresince iyiye giden, 1921 Moskova Antlaşması ile tescillenen ve 1925 Antlaşması ile yenilenen dostluk ilişkileri1939 yılında Sovyetler Birliği’nin bazı istekleri - toprak talebi gibi - nedeniyle birden bozulmaya başladı. Sovyetler'in bu tutumunun da etkisiyle, Türkiye’nin gerek Sovyetlerle gerek Almanya ile dostluk ve saldırmazlık antlaşmaları bulunmakla birlikte, Türkiye SSCB karşısında Almanya'nın savaşı kazanmasını istemekteydi. Bu istek siyasiler ve basın tarafindan değişik şekilde ifade edilmekteydi. Tabi ki Ruslar da bunun farkındaydılar. Türkiye Ekim 1941'de Almanya ile Türk-Alman Ticaret Antlaşması'nı imzaladı ve iki ülke arasındaki ticaret hacmi genişledi (Koçak, 2017: 600-601, 633). Bu ve buna benzer gelişmeler Sovyetler'i rahatsız etmekteydi. Nihayet SSCB 1925 tarihli Türk-Sovyet Dostluk ve Saldırmazlık Antlaşması'nı Mart 1945'te feshederek anlaşmanın yeniden imzalanması için Türkiye'nin yerine getirmesi gereken bazı şartların olduğunu Türk yetkililere bildirdi. Bu şartlar, herhangi bir devletin yerine getirebileceği özelliklerden uzaktı. Bu şartlardan, birincisi1878 Berlin Antlaşması ile ele geçirdiği ancak Ekim Devrimi sonrası Türkiye'ye bıraktığı topraklar olan Kars ve Ardahan'ın Sovyetler Birliği'ne verilmesi, ikincisi de boğazlarda Sovyetler'e üs kurma hakkının tanınmasıydı. Stalin, Çarlık Rusya'sı topraklarını geri almak istemekteydi. Bu Finlandiya, Polonya, Çekoslovakya, Romanya ve Türkiye'den toprak, Latvia, Estonya, Litvanya'yı egemenliği altına almak demekti (Akşin, 2012: 239). 
Savaş sonrasında İngiltere ile Sovyetler Birliği arasında işbirliğini güçlendirmek için 17 Temmuz 1945 - 2 Ağustos 1945 tarihleri arasında gerçekleşen Potsdam Konferansı'nda konuşulan konulardan bir tanesi, SSCB'nin gündeme getirdiği Boğazlar meselesidir. Sovyetler Birliği, boğazlar meselenin sadece Türkiye ile kendileri arasında çözülmesi gereken iki taraflı bir mesele olarak değerlendirmiş ve boğazlarda üs kurma isteğini dile getirmiştir (Sarınay, 2018).Sovyetler Birliği 7 Ağustos 1946 tarihinde verdiği notada Türkiye'nin II. Dünya Savaşı sırasında mihver güçlerinin savaş gemilerine izin vererek boğazlardaki yetkilerini kötüye kullandığını beyan etmekte, bundan sonrası için "ticaret ve geliş-geçiş serbestliği ile boğazların güvenliğinin, en ziyade ilgili ve bu işe en liyakatli devletler olan Sovyet Rusya ile Türkiye tarafindan ortak vasıtalarıyla sağlanması" [Armaoğlu, (t.y): 428] gerektiğini bildirmekteydi. Bu süreçte, Sovyetler'in uyguladığı baskı karşısında Türkiye, en büyük desteği ABD ve İngiltere'den buldu.

SSCB'nin toprak talebi ve boğazlarda üs kurma isteği Türkiye'yi ciddi anlamda tedirgin etmiş, dönemin Türkiye'deki sosyo-ekonomik koşullar bir savaşa girmeyi göze almaya olanak sağlayacak gibi değildi. Bunun yanında Türkiye’nin kendisini güvenceye alabileceği, ABD’nin öncülük ettiği bir blok oluşmaktaydı. Bu blok, aynı zamanda Sovyet tehdidi karşısında Türkiye'ye güvence verecek güce sahipti. Türkiye bu bloğa dahil olmaya karar verdi. Nitekim İsmet Paşa CHP içinde Recep Peker gibi demokratik sisteme sıcak bakmayan muhalif gruba rağmen 19 Mayıs 1945 tarihindeki konuşmasında, cumhuriyetin halk iradesine dayalı olarak kurulduğunu ve halk iradesinin Savaş sonrasında demokrasi prensipleri biçiminde siyasal sistemde son şeklini alacağını ifade etmiştir (Dursun, 1999: 37).

\section{SONUÇ}

Osmanlı Devleti'nde Sened-i İttifak dönemi ile başlayan ve Tanzimat ile şekillenen siyasal iktidarın anayasal sınırlar içine çekilmesi, II. Meşrutiyet döneminde çok partili rekabetçi kurumların siyasal yaşamda boy göstermesine kadar varmış, İttihat ve Terakki Fırkası'nın 1913'te bir takım gerekçelerle bu sürece son vermesiyle 1946'ya kadar Türkiye'de, genel anlamda, tek parti rejimi hakim olmuştur. 1946 yılında çok partili hayata geçilmesi, Türkiye demokrasisi açısından en önemli dönemi oluşturduğu söylenebilir. Çünkü bundan sonrası için askeri darbelerle bu süreç kısa süreliğine sekteye uğratılmış olsa da, demokrasinin kurum ve kurallarının belli ölçüde yerleşmeye başladığı görülmektedir. Bu anlamda çok partili hayata geçiş süreci rekabetçi bir düzenin oluşmasının temelini oluşturmaktadır.

Türkiye'nin çok partili rekabetçi siyaseti benimsemesinin iç ve diş nedenleri vardır. Genel bir çerçeve olarak; 
Birincisi, II. Dünya Savaşı'nın da etkisi ile ekonomik koşulların özellikle dar ve sabit gelirli kesimler için kötüleşmesi ve otoriter-baskıcı devlet anlayışının uyguladığı baskının siyasal iktidarın geniş toplumsal kesimler için meşruiyetini büyük ölçüde kaybetmesi,

İkincisi, iktidarın başına buyruk uygulamalarının sermaye gruplarının kazanımları için tehdit oluşturması ve bu kesimlerin sahip oldukları sermaye ile iktidardan pay almak istemeleri,

Üçüncüsü, II. Dünya Savaşı'nın son bulması ile diktatörlük rejimlerinin cazibesini kaybetmesi ve rekabetçi liberal değerlerin hakim popüler değerler haline gelmesi,

Dördüncüsü, Türkiye ekonomisinin içinde bulunduğu dar boğazdan ABD ve Batı'nın ekonomik desteği ile kurtulabileceği umudu,

Beşincisi ise Sovyetler Birliği'nin boğazlar ve toprak talebi gibi konularda Türkiye için bir beka sorunu haline gelmesi ve buna bağlı Batı'nın güvenlik şemsiyesine ihtiyaç duyulması, Türkiye'nin çok partili hayata geçişinin iç ve dış nedenleri olarak düşünülebilir.

Türkiye'nin çok partili rekabetçi hayata geçişinde etkili olan unsurlardan Sovyetler Birliği'nin tehdidi, ABD ve Batı'nın ekonomik ve siyasi desteğini almak gibi dış nedenlerin belirleyici, iç nedenlerin ise bunu tamamlayıcı bir özellik oluşturduğu söylenebilir. Bu dönemde, halkın iktidardan rekabetçi bir siyasete geçiş ile ilgili bir talebi yoktu. Halkın mevcut iktidarı istemediği söylenebilir ama bu demokratik sistemin seçilme yolların talep etmek anlamına gelmemektedir. $\mathrm{Bu}$ anlamda, kahir ekseriyeti köylerde yaşayan halkın sadece kendilerine daha iyi davranacak bir iktidar istedikleri söylenebilir.

Sened-i İttifak'tan bu yana siyasal iktidarın sinırlandırılması konusunda yaşanan gelişmelerin hiç birinde halk yer almamıştır. Bu alandaki rekabet aydın, sivil ve askeri bürokrat elitlerin kendi aralarında güttükleri bir mücadeledir. Çok partili hayata geçiş süreci de bu gelişmenin bir parçasını oluşturmaktadır.

Dış dinamiklerin Türkiye siyasetini belirlemede oynadığı rol hayati bir öneme sahiptir. Bunun geçmişi Osmanlı İmparatorluğuna kadar uzanmaktadır. Tanzimat Fermanı ile Islahat Fermanı, Batı güçlerinin Osmanlı'ya kabul ettirdikleri hukuki belgelerdir. Bunun yanı sıra, padişah Kanun-i Esasi'yi ilan etmekle 1877-1878 Osmanl1-Rus Savaşı'nda desteklerini almak için Avrupa devletlerine Osmanlı Devleti'nin onlar gibi parlamenter bir devlet olduğunu göstermek istemiştir. Aynı şekilde, çok partili hayata karar verilmesinde Rusya'nın oluşturduğu tehdit ve Bat1 güçlerinin Türkiye'nin çok partili hayata geçmesi gerektiği yönündeki baskıları etkili olmuştur. Günümüzde demokratikleşme adına atılan adımlarda da, 
Avrupa Birliği'nin üyesi olmak umuduyla büyük ölçüde, Avrupa ülkelerinin 1srarı belirleyici olmaktadır.

\section{KAYNAKÇA}

Ahmad, Feroz (2015), Demokrasi Sürecinde Türkiye, Hil Yayınları, İstanbul.

Ahmad, Feroz (1995), Modern Türkiye'nin Oluşumu, Sarmal Yayınevi, İstanbul.

Akandere, Osman (1998), Milli Şef Dönemi, Çok Partili Hayata Geçişte Rol Oynayan İç ve Dış Tesirler, 1938-1945, İz Yayıncılık, İstanbul.

Akınc1, Abdulvahap ve Usta, Sefa (2015), “Türkiye'de Çok Partili Hayata Geçişte Etkili Olan İç Faktörlerin Analizi”, KMÜ Sosyal ve Ekonomik Araştırmalar Dergisi, Cilt: 17, Sayı: 29, ss. 41-52.

Akşin, Sina (2012), Kısa Türkiye Tarihi, İş Bankası Yayınları, İstanbul.

Armaoğlu, Fahir (t.y), 20. Yüzyıl Siyasi Tarihi, Alkım Yayınevi, İstanbul.

Aydemir, Şevket Süreyya (2016), İkinci Adam 1938-1950, Remzi Kitabevi, İstanbul.

Baysal, Kubilay (1984),Türkiye Ekonomisi, İstanbul Üniversitesi Yayın No: 3236, İstanbul.

Çalık, Mustafa (1989), "Batılılaşma ve Bürokratik Modernleşme Münasebeti Üzerine Bazı Düşünceler” Türkiye Günlüğü, Say: 2, ss. 6-15.

Çavdar, Tevfik (2004),Türkiye’nin Demokrasi Tarihi, İmge Kitabevi, Ankara.

Çufal1, Mustafa, "Cumhuriyet Döneminde Çok Partili Hayata Geçişte Rol Oynayan Dinamikler”, liberal.org.tr/Mustafa_Cufali.pdf, (05.12.2018).

Dursun, Davut (1999), Demokratikleşemeyen Türkiye, İşaret Yayınları, İstanbul.

Eğilmez, Mahfi (2018), Değişim Sürecinde Türkiye, Remzi Kitabevi, İstanbul.

Erdoğan, Mustafa, “Türkiye'de Demokrasiye Geçiş Deneyimi (1945-1960)”, http://www.liberal.org.tr/sayfa/turkiyede-demokrasiye-gecis-deneyimi1945-1960-mustafa-erdogan, 349.php (20.12.2018). 
Haytoğlu, Ercan (1997), “Türkiye'de Demokratikleşme Süreci ve 1945’te Çok Partili Siyasi Hayata Geçişin Nedenleri (1908-1945)”, PAÜ Eğitim Fakültesi Dergisi, Sayı: 3, ss. 46-56.

İnalcık, Halil (1990), “Osmanlı Toplum Yapısının Evrimi” Türkiye Günlüğü, Say1: 11, ss. 30-41.

İnan, Afet (1983), Mustafa Kemal Atatürk'ün Karsbad Hatıraları, Türk Tarih Kurumu Yayınları, Ankara.

İşyar, Ömer Göksel (2009), Karşılaştırmalı Dış Politikalar, Dora Yayınları, Bursa.

Kaan, Oğuz (2008), II. Meşrutiyet Döneminde Muhalefet: Ahrar Fırkası, İstanbul Üniversitesi Sosyal Bilimler Enstitüsü (Yayınlanmamış Doktora Tezi), İstanbul.

Kahraman, Hasan Bülent (2010),Türk Siyasetinin Yapısal Analizi-II 19201960, Agorakitaplığ 1 , İstanbul.

Kara-İncioğlu (2007), “Türkiye'de Çok Partili Sisteme Geçiş ve Demokrasi Sorunları", Türkiye'de Politik Değişim ve Modernleşme, (Der. Kalaycıoğlu, Ersin - Sarıbay, Ali Yaşar), Alfa Aktüel, İstanbul, ss. 253266.

Karpat, Kemal (2017), Türk Demokrasi Tarihi, Timaş Yayınları, İstanbul.

Karpat, Kemal (2012), Türk Siyasi Tarihi, Timaş Yayınları, İstanbul.

Kepenek, Yakup (2014), Türkiye Ekonomisi, Remzi Kitabevi, İstanbul.

Keyder, Çağlar (2005), “1990'larda Türkiye'de Modernleşmenin Doğrultusu", Türkiye'de Modernleşme ve Ulusal Kimlik, (Ed. Bozdoğan, Sibel - Kasaba, Reşat), Tarih Vakfı, İstanbul, ss. 29-42.

Koçak, Cemil (2017), Türkiye'de Milli Şef Dönemi (1938-1945), İletişim Yayınlar, İstanbul.

Kongar, Emre (1995), Türkiye'nin Toplumsal Yapısı, Remzi Kitapevi, İstanbul.

"Köylülerin Toprak Rüyası Nasıl Kabusa Döndü”, https://www.ulusal.com.tr/yurt/koylulerin-toprak-ruyasi-nasil-kabusadondu-h107014.html, (21.12. 2018). 
Lewis, Bernard (1996), Modern Türkiye'nin Oluşumu, Türk Tarih Kurumu Yayınları, Ankara.

Örmeci, Ozan (2008), Türk Siyasal Hayatı, Güncel Yayınları, İstanbul.

Özcan, Feridun Cemil (2016), “Ellili Yıllarda Türkiye Ekonomisi”, Türkiye'nin 1950'li Yılları, (Haz. Kaynar, Mete Kaan), İletişim Yayınları, İstanbul, ss. 39-67.

Özdemir, Nuray (2013), “Cumhuriyet Döneminde Türkiye’de Yol Vergisi”, Tarih Araştırmaları Dergisi, Cilt: 32, Sayı: 53, ss. 213-247.

Sancaktar, Caner (2012), “Türkiye’de Çok Partili Rekabetçi Siyasetin Doğuşu: Siyasal Değişimin İç ve Dış Dinamikleri”, Bilge Strateji, Cilt: 4, Say1: 7, ss. 31-64.

Sarıbay, Ali Yaşar (2001), Türkiye’de Demokrasi ve Politik Partiler, Alfa Yayınları, İstanbul.

Sarınay, Yusuf, “Türkiye'nin Nato'ya Girişi”, www.tarihtarih.com/?Syf=26\&Syz=354664\&/Türkiye'nin-Natoya-Girișiyrd.-Doç.-Dr.-Yusuf-Sarınay-(04.11.2018).

Shaw, Stanford ve Shaw, Ezel Kural (2000), Osmanlı İmparatorluğu ve Modern Türkiye, E Yayınları, İstanbul.

Sönmezoğlu, Faruk (2012), “Türkiye Cumhuriyeti’nin Dış Politikasında Süreklilik ve Değişim", Türk Dış Politikası'nın Analizi, (Der. Sönmezoğlu, Faruk - Baklacioğlu, Nurcan Özgür - Terzi, Özlem), Der Yayınları, İstanbul.

Tezel, Yahya (2015), Cumhuriyet Döneminin İktisadi Tarihi, Türkiye İş Bankası Yayınları, İstanbul.

Timur, Taner (1991), Türkiye'de Çok Partili Hayata Geçiş, İletişim Yayınları, İstanbul.

Tuna, Serkan (2007), “Cumhuriyet Ekonomisinin İlk Devalüasyonu: 7 Eylül 1946”, Akdeniz Üni. İïF Dergisi, Cilt: 13, Say1: 7, ss. 86-121.

Yeşil, Ahmet (1988), Türkiye'de çok Partili Siyasi Hayata Geçiş, T.C. Kültür Bakanlığı Yayınları, Ankara.

Zürcher, Erik Jan (2005), Modernleşen Türkiye'nin Tarihi, İletişim Yayınları, İstanbul. 